\title{
“Em direcção ao vazio ou a qualquer coisa": os ecrãs e as ligações quotidianas sociotécnicas
}

José Pinheiro Neves"

Zara Pinto-Coelho"*

Neste número da revista Comunicação e Sociedade dedicado aos "Ecrãs e ligações sociotécnicas”, estamos especialmente interessados numa compreensão transdisciplinar dos ecrãs do computador, cinema e vídeo que estão incorporados na nossa experiência quotidiana.

A sociedade pós-moderna da imagem em que vivemos, sendo, através dos ecrãs, um conjunto de ligações cada vez mais aditivas, devém de uma sociedade de controlo difuso abandonando o modelo anterior baseado na disciplina e na estabilidade das ligações (Deleuze, 1992; Foucault, 1975). Na verdade, a ética moderna do trabalho dava-nos uma estabilidade para conduzir a nossa vida acreditando que, no final, uma boa reforma baseada no nosso sacrifício seria um pouco o céu na terra. Todavia, toda esta crença começa pouco a pouco a ser corroída com o neoliberalismo selvagem e a indefinição na nossa relação com um trabalho cada vez menos físico e assente em relações cada vez menos solidárias.

Neste esvaziamento, começamos a tentar coisas novas, uma espécie de vagabundagem centrada no emocional que tanto nos pode libertar como pode aumentar a insatisfação e levar-nos para novas dependências. É aqui que surge o fenómeno das nossas ligações com os ecrãs digitais como uma saída (em grande parte ilusória) para esta crise do mundo moderno. De acordo com Sennet (2004), estando cada vez mais isolados dos velhos laços da comunidade, pela paixão dos interesses privados, e também dos mais próximos afectivamente, pela degradação do trabalho e pela volubilidade sentimental, erramos em direcção ao vazio ou a qualquer coisa.

A satisfação imediata e rápida assente num consumo acelerado, usando em grande parte a Internet e os novos media digitais, torna-se o nosso lema. O uso quotidiano dos

\footnotetext{
* Centro de Estudos de Comunicação e Sociedade (CECS), Universidade do Minho, jpneves@ics.uminho.com.

* Centro de Estudos de Comunicação e Sociedade (CECS), Universidade do Minho, zara@ics.uminho.pt.
} 
ecrãs digitais, a moda da amizade fast-food, do sexo e dos jogos online parece ser o nosso destino comum. Desta forma, esta via esgotada do capitalismo, de uma forma de "ser" assente no assalariado e na ética do trabalho, dá lugar a um novo niilismo, a uma crise que tanto nos pode levar a um afundar cada vez maior no consumo dos media digitais e nas relações sociais fast-food, como pode fazer emergir coisas novas, socialidades alternativas e mais criativas de vida, e de relação com a morte como diria Maffesoli (2002). Por isso, a experiência quotidiana das imagens-ecrã pode caracterizar-se, em grande parte, pelo empobrecimento da experiência perceptiva ou por uma alucinação colectiva semelhante ao que se passa nas experiências dos alucinogénios. A nova sociedade funciona cada vez mais por controlo contínuo e por comunicação instantânea, em fluxo, deixando de ser tão relevantes os tradicionais “encerramentos" das sociedades disciplinares, havendo uma passagem de uma dependência espacial para uma dependência temporal contínua.

Em muito do que fazemos e do que é feito connosco, do que percepcionamos e do que pensamos, dificilmente conseguimos estar separados dos ecrãs. Contudo, os perigos desta mudança são enormes. Tal como diz Tereza Cruz (2002), “das novas coisas, não tenhamos a ilusão de serem meros objectos, sobre os quais temos ainda a confortável distância da representação ou da instrumentalidade”. Estamos perante uma situação de fragilidade que apenas poderá ser combatida por uma consciência aguda e activa do que se passa. Necessitamos urgentemente de repensar, de forma clara, as nossas formas de vida e de pensamento, fortemente apoiadas na técnica. As novas formas da técnica, ligadas à informação digitalizada, afectam a experiência contemporânea e obrigam-nos a repensar os conceitos tradicionais das ciências sociais herdados da modernidade (Martins, 2002). Surgem, a todo o momento, conceitos novos que desestabilizam as formas tradicionais adoptadas pelas ciências sociais: cibercultura, cultura digital, experiência electrónica e virtual, etc. (Lemos, 2003). Esta mudança é um sintoma de uma crise que não só passa pelas práticas do pensamento mas que também atravessa outras práticas, outras experienciações do mundo. Como afirma Bragança de Miranda (2005), "nunca se falou tanto de técnica como no momento em que a sua essência parece ocultar-se por de trás da evidência da sua presença, da variabilidade das suas formas e agenciamentos".

É esse o objectivo deste número da revista. Recorrendo a contribuições de várias áreas do conhecimento, pretende criar uma maior lucidez que nos faça ver os perigos e potencialidades emergentes desta situação tecno-humana e, nessa medida, fomentar o debate e completar a bibliografia sobre esta temática.

Gabriel Menottii, no seu artigo, leva-nos “através da sala escura”, chamando a atenção para as condições e as transformações efectuadas ao nível da distribuição e exibição do cinema, resultantes das potencialidades oferecidas pela imagem digital, ao mesmo tempo que salienta as potencialidades do filme digital e do "Vjing". O autor sustenta, apoiado em Friedberg (1994), que o "Vjing" possibilita novas explorações cinematográficas, onde o dispositivo, o espaço e os espectadores "se encontram em estado virtual e mobilizado". Retomando uma velha dicotomia no debate sobre o cinema, realistas versus formativos, Victor Flores explica como a limpidez e a alta definição 
das imagens digitais são afectadas por uma "cultura visual das lentes", responsável pela incorporação de certos hábitos de usufruição das imagens provenientes da era do analógico, revelando um impulso de continuidade constante dos novos media digitais. Com Paulo Pinheiro e Eugénia Cabral passamos do ecrã do cinema para a fotografia, e a sua relação com os ecrãs, sugerida pela ideia de que as fotografias em formato screen afectam a forma como as interpretamos, usamos e recordamos. "A tela na cidade" de Denise Siqueira explora o caso do videoclipe brasileiro, a forma como reflecte o imaginário social sobre os jovens no espaço urbano e as possibilidades de mobilidade e de novas socialidades que implica. Sobre a relação de poder que atravessa a experiência dos ecrãs, do ponto de vista estético, e do ponto de vista utilitário, sustentado em leituras de Benjamin, Flusser, Borgmann e Manovich, fala-nos Pedro Mendonça. O autor sublinha que a hibridez artística e funcional do ecrã e as suas inúmeras potencialidades co-actuam com os inúmeros poderes escondidos na maquinaria, funcionando assim como um enquadramento do poder, que dá a ver e simultaneamente esconde. Lúcio Sequeira aborda o tema da relação social com os blogues, procurando discutir a necessidade que os usuários sentem "em ser vistos", sustentado em leituras de Michel Foucault, Erving Goffman, Guy Debord e Eric Landowski.

Dos blogues passamos ao jornalismo e às novas formas de televisão. Ana Luísa Ribeiro aborda o jornalismo online, as mudanças das práticas de leitura introduzidas por este novo tipo de jornalismo, a partir de um estudo empírico com leitores de um título brasileiro. Ainda neste campo, mas relativamente ao ecrã televisivo, Ana Melro, Helena Carvalho, Mariana Sousa e Vítor de Sousa discutem a interacção televisiva e a sua (des)ordem, a propósito da entrevista televisiva, e de um caso particularmente recente no panorama português envolvendo a TVI. Por fim, no texto de Walter Lima e Lima Hora, revisitamos a evolução dos conceitos de interface na TV digital ao longo da história, destacando o modelo adoptado no Brasil. O autor defende que a TV digital não é apenas uma evolução da TV analógica, mas um "dispositivo estendido, um display periférico que surge das potencialidades computacionais."

\section{Referências bibliográficas}

Cruz, M. T. (2002) “O artificial ou a era do design total”, Revista Online de Arte, Cultura e Tecnologia, [http://www.intearct.com.pt, consultado a 15 de Setembro de 2006].

Deleuze, G. (1992) "Postscript on the Societies of Control”, October, Vol. 59. (Winter): 3-7.

Foucault, M. (1975) Surveiller et punir, Paris: Éditions Gallimard.

Lemos, A. (2003) "Cibercultura. Alguns pontos para compreender a nossa época" in Lemos, A.; Cunha, P. (orgs.), Olhares sobre a cibercultura, Porto Alegre: Sulina, pp. 11-23.

Maffesoli, M. (2002 [1988]) Le Temps des tribus, Le déclin de l'individualisme dans les sociétés postmodernes, Paris: La Table Ronde, $3 .^{\mathrm{a}}$ ed.

Martins, M. de L. (2002) "De animais de promessa a animais em sofrimento de finalidade", O Escritor, n. ${ }^{\circ}$ 18/19/20: 351-354.

Miranda, J. B. “Cibercultura: crítica do eros tecnológico. Resumo”. [http://pwp.netcabo.pt/jbmiranda/ mestrd_05.ht, consultado a 3 de Abril de 2005].

Sennet, R. (2004) A corrosão do caráter. As consequências pessoais do trabalho no novo capitalismo, Rio de Janeiro: Editora Record. 